\title{
Statyba
}

\section{ANALYSIS OF EXPERIMENT AND CALCULATION OF THE THREADED JOINTS UNDER TENSION AND CYCLIC BENDING}

A. Krenevičius , S. Stupak , M. Šukšta \& M. Leonavičius

To cite this article: A. Krenevičius , S. Stupak , M. Šukšta \& M. Leonavičius (1999) ANALYSIS OF EXPERIMENT AND CALCULATION OF THE THREADED JOINTS UNDER TENSION AND CYCLIC BENDING, Statyba, 5:3, 170-175, DOI: 10.1080/13921525.1999.10531458

To link to this article: https://doi.org/10.1080/13921525.1999.10531458

Published online: 26 Jul 2012.

Submit your article to this journal $₫$

Щ Article views: 65 


\section{TEMPIAMU IR CIKLIŠKAI LENKIAMU SRIEGINIŲ JUNGČIU BANDYMỤ IR SKAIČIAVIMU ANALIZE்}

\section{A. Krenevičius, S. Stupak, M. Šukšta, M. Leonavičius}

\section{Ivadas}

Jau projektuojant numatoma, kad irąžos nevienodai pasiskirstys tarp konstrukcijos elementų. Tačiau skaičiuojamoji schema ne visada atitinka realios konstrukcijos darbą. Dèl nedideliụ projektavimo, gamybos ir surinkimo technologijos paklaidu eksploatacijos metu kai kurių elementų įtempimai būna didesni, negu buvo numatyta. Antai metalinių konstrukcijų ir irenginių srieginiu jungčių ir kitų elementų itempimai dèl konstrukciniu technologiniu ir eksploataciniu ypatumu kinta cikliškai ir kai kuriose srityse gali pasidaryti didesni už takumo itempimus. Jau projektuojant reikia atskirai nagrinetti kartotinius kintamus apkrovos komponentus ir nustatyti, koki kvazistatinio ar ciklinio apkrovimo ribini būvi jie gali sukelti, kokiu konstrukcijos elementu pažeidimų galima tikètis.

Paprastai srieginès jungtys apkraunamos tik ašinèmis jègomis, kintančiomis asimetriniu ciklu. Srieginiai jungiamieji elementai eksploatuojant gali būti apkrauti ciklinèmis jègomis, kintančiomis simetriniu, asimetriniu arba pulsuojančiu ciklu. Konstrukciniai ypatumai, jungčių ir jungiamu detalių poveikis pakeičia sistemos varžtas-veržlè apkrovimo sallygas taip, kad pasireiškia ne tik tempimas, bet ir lenkimas, o suminiai itempimai gali pasiekti plastinę sriti.

Nuo pat stiprumo mechanikos laboratorijos ikūrimo buvo atliekami tempiamų ir cikliškai lenkiamų srieginiu jungciu eksperimentiniai ir teoriniai tyrimai. Eksperimentinių tyrimų metodika apemė jau žinomus bandymo metodus ir nuolat buvo tobulinama, siekiant užtikrinti išbandomų srieginių jungčiu toki apkrovima, kuris maksimaliai atkuria realiu jungčiı darbo salygas. Itempimu būvis, plyšio susidarymo sąlygu analizè ir eksperimentiniu tyrimy rezultatai, pateikti darbuose [1-8], rodo atsparumo cikliniam irimui, prisitaikymo proceso sudetingumą ir desningumus, kuriuos pavyko nustatyti eksperimentiniais ir teorinjais tyrimais. Šiame straipsnyje apžvelgiami kai kurie tempiamų ir cikliskai lenkiamų srieginių jungčiu tyrimo ir skaičiavimo ypatumai.

\section{Eksperimentinis tyrimas}

Lenkimo apkrova atsiranda dèl ịvairių priežasčių: gamybos netikslumo, sujungiamu elementu poveikio ir mazgo konstrukciniu ypatumu. Dèl gamybos netikslumo gali atsirasti pokrypis tarp varžto galvutes (veržlès) atraminio paviršiaus ir sujungiamo elemento paviršiaus. Be to, sujungiami elementai del išoriniu jègu poveikio gali taip deformuotis, kad neišvengiamas vienpusis salytis tarp veržlès ir elementy atraminiu paviršiu. Prieštaravimas tarp sujungiamų mazgu konstrukciniu ypatumų ir srieginèms jungtims keliamų reikalavimų realioje konstrukcijoje gali pasireikšti iražǔ persiskirstymu. Tam tikromis priemonèmis lenkimo itempimus galima sumažinti ir projektuojant:

a) didinant varžto (smeigès) paslankuma;

b) mažinant salyčio paviršiu paslankuma:

c) didinant sujungiamų elementų standuma;

d) naudojant specialias sferines ir kūgines poveržles.

Visos šios priemonès tik šiek tiek sumažina lenkimo itempimus, o energetikos irenginiu ir kitose konstrukcijose sujungiami elementai daro toki poveiki srieginems jungtims, kad lenkimo itempimus reikia iskaičiuoti jau projektuojant.

Darbuose [1-7, 9] nagrinejamas tempiamy ir lenkiamų srieginių jungcių atsparumas statiniam ir cikliniam apkrovimui. Lenkimo momentas sukuriamas ivairia iranga. Tyrimuose, kuriuose naudojama įstriža poveržlè (nuožulos kampas iki $6^{\circ}$ ), nèra aiškaus santykio tarp tempimo ir lenkimo itempimy skirtingomis apkrovimo salygomis. Po iveržimo varžto (smeigès) skerspjūvyje veikia ịveržimo jèga $N$ ir lenkimo momentas $M$, o itempimai nuo lenkimo apskaiciuojami iš lygties:

$$
\sigma_{m}=2 \sqrt{\sigma_{n}} \frac{\gamma \sqrt{E}}{\operatorname{th}\left(\frac{4 l_{0}}{d} \sqrt{\frac{\sigma_{n}}{E}}\right)}
$$


$\sigma_{n}-$ itempimai nuo tempimo, $\quad \gamma$ - smeigès pokrypio kampas, $l_{0}, d$-geometriniai smeigès parametrai, $E$ - tamprumo modulis.

Mũsu darbuose statiniams ir mažacikliams bandymams taikyta speciali metodika. Itvirtinimo griebtuvu konstrukcijoje tempimo jèga $F$ pridèta ekscentriškai ( $e-$ keičiamas) srieginès jungties atžvilgiu. Maksimalūs j̇tempimai nuo tempimo ir lenkimo apskaičiuojami iš lygties:

$$
\sigma_{\max }=\frac{4 F}{\pi d^{2}}\left(1+\frac{8 e}{d}\right)
$$

Ši metodika pranašesnè už poveržlès su nuožula metoda. Tyrimai [10] parodè, kad atsparumas mažacikliam nuovargiui pradeda mažèti, palyginti su cikliškai tempiamomis jungtimis, jeigu lenkimo itempimai viršija ketvirtadali tempimo itempimu $\left(\sigma_{m}>0,25 \sigma_{n}\right)$. Tačiau ir ši metodika neatkuria srieginių jungčių darbo realiose konstrukcijose.

Paprastai tempimas susidaro iveržiant sriegines jungtis ir siekia $0,8 \sigma_{y}$. Srieginèms jungtims iveržti surinkimo metu taikomi specialūs metodai, kuriais gali būti išmatuotas ịtempties dydis: veržlès pasukimas, reguliuojant užveržimo momentą; smeigès pakaitinimas surinkimo metu; smeigès ištempimas prieš pasukant veržles ir kt. Vèliau per sujungiamus elementus varžtai (smeigès) gali būti apkrauti cikliškai kintamomis tempimo arba lenkimo apkrovomis.

Specialia bandymo metodika ir iranga, skirta srieginiu jungčiu M16...M52 bandymui $[2,6]$, atkuriamos standaus tempimo ir lenkimo salygos, susidarančios kai kuriose realiose konstrukcijose. Smeigiu ir veržliu pagrindiniai geometriniai parametrai atitinka normatyvinius reikalavimus [11-15]. Tempimas susidaro nuo itempties, gaunamos specialiu bandymo mašinos itaisu. Smeige ištempiama ir tuo pačiu metu pasukama apatinè veržlè. Pašalinus apkrovą, matuojamas ịtempties dydis. Periodiškai ištempiant smeige ir pasukant veržlę gaunamas norimas itempties dydis ir tarpiniu detaliu iveržimas.

Taip surinkta srieginè jungtis kartu su tarpinèmis detalèmis itvirtinama bandymo mašinoje, kuri suderinama darbui pagal poslinki. Apkrovimo ciklo parametrai kontroliuojami bandymo mašinos prietaisais.

Tarp daugelio veiksnių, lemiančių sistemos varžtas-veržlè ciklini stiprumą, vienas iš svarbesnių yra iražž pasiskirstymas. Irąžų pasiskirstymui tarp sriegio vijų skiriami specialūs eksperimentiniai ir teoriniai ty- rimai, nustatomos sistemos varžtas-veržlè darbo sąlygos, labiausiai apkrautos vietos padètis smeigès juuboje, parenkama jungties konstrukcija.

Irąžų pasiskirstymo désningumų tyrimui naudotos srieginès jungtys M52×4 iš plieno $38 X H 3$ MФA. Mechaninès savybès termiškai apdorojus: $\sigma_{t 2}=900 \mathrm{MPa}$, $\sigma_{u}=910 \mathrm{MPa}, \Psi=59 \%$. Sriegio jdubos profilis suapvalintas spinduliu $R=(0,12 \ldots 0,14) P$, čia $P$ - sriegio žingsnis. Veržlių aukštis $1,8 d$, išorinis skersmuo $1,6 d$, čia $d$ - išorinis smeigès skersmuo. Tarpelis sriegyje sudare $0,3 \ldots 0,4 \mathrm{~mm}$. Apkrovimo režimai:

1) $\bar{\sigma}=(0,6 \pm 0,35) \sigma_{y}-10$ ciklu;

2) $\sigma=(0,6 \pm 0,45) \sigma_{y}-200$ ciklų.

Irą̌ǔ pasiskirstymas iveržus srieginę jungti iki $\sigma_{t}=\sigma_{y}$, parodytas 1 pav., atitinka bendruosius dèsningumus, būdingus tempiamoms jungtims (tempiama smeigè ir gniuždoma veržlè). Pirmame apkrovimo cikle viju jdubose dèl lenkimo tempiamuose sluoksniuose deformacijos taip pat atitinka bendruosius tempiamy jungčių irązụ pasiskirstymo dèsningumus. Gniuždomuose sluoksniuose bendras itempties ir veržlès poveikis iškraipo žinomus dèsnius. Taip pat parodytos deformacijos smeigès itemptosios dalies vijos iduboje (1 pav. laisva vija), kuri nutolusi per sriegio žingsni nuo veržlés.

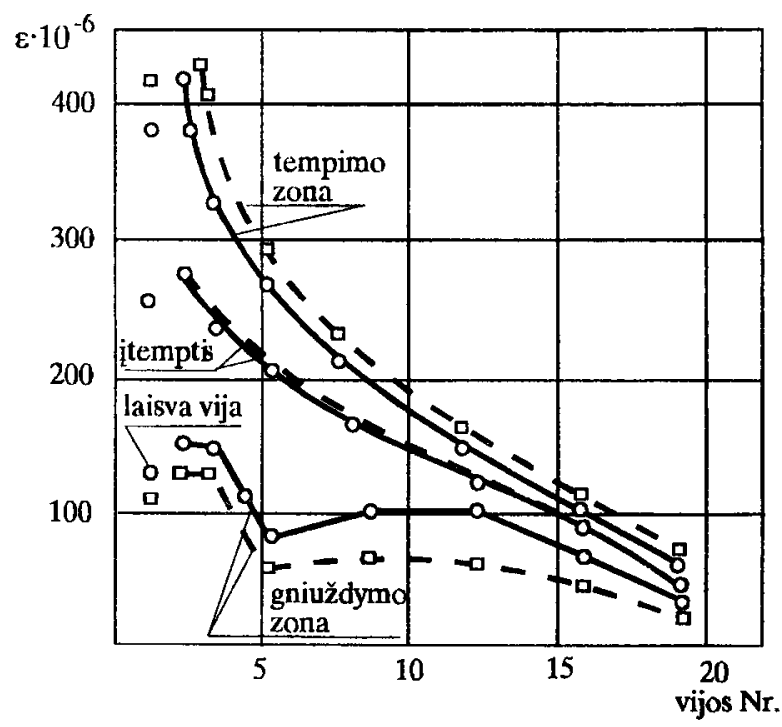

1 pav. Deformacijos atskirose smeigès vietose:

O- $=(0,6 \pm 0,35) ; \quad \square-=(0,6 \pm 0,45)$

Fig 1. Deformations in different turns of the stud: O - $=(0,6 \pm 0,35) ; \quad \square-=(0,6 \pm 0,45)$

Eksperimentas parodè, kad dèl lenkimo sukeliamy itempimy padidejimo nuo $0,35 \sigma_{y}$ iki $0,45 \sigma_{y}$ 
proporcingai iražos 1 ir 2 vijose nepadideja. Toliau deformuojant iki 200 ciklu iražų pasiskirstymo dèsningumai nepasikeičia. Maksimalūs įtempimai gaunami lenkimo plokštumoje nepriklausomai nuo veržlès ir smeigès tarpusavio padeties, tačiau veržlès padetis turi itakos plyšio atsiradimo ir plitimo sąlygoms. Ivertinant toki irąžu pasiskirstymą viena iš veržliu pastatoma ị atitinkamą padèti, o kita užima savo vietą priklausomai nuo ịveržimo dydžio.
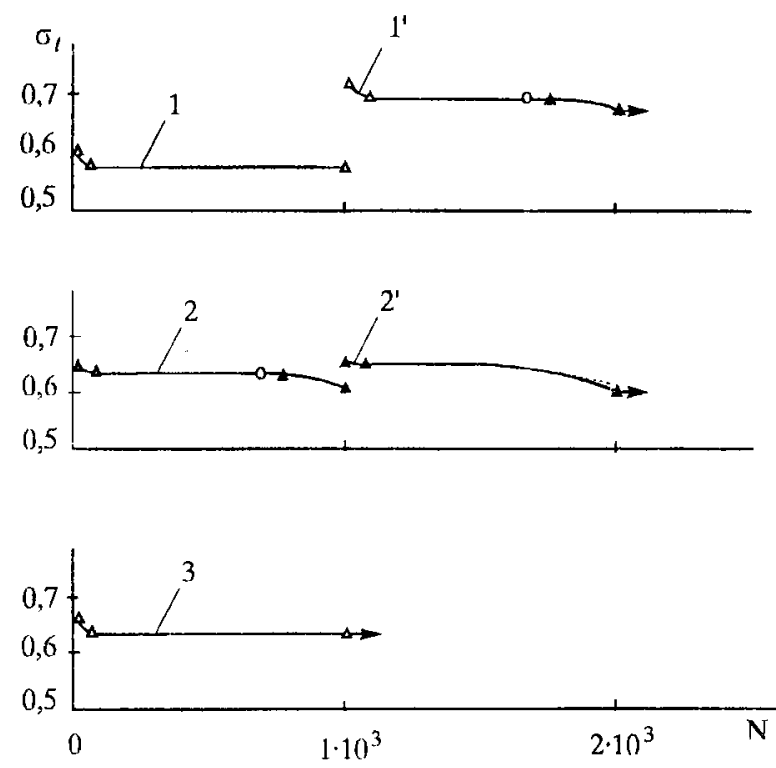

2 pav. Srieginiu jungčiụ M52 $\times 4$ itempties kitimas: $\Delta$ - matavimų ribos: $\mathbf{A}$ - matavimų ribos atsiradus plyšiui; O- plyšio atsiradimas; $\Delta \cdot \Delta \rightarrow \quad-$ bandymas nutrauktas; ... - liekamosios deformacijos lenkimo plokštumoje

Fig 2. Change in tightening threaded joints M52×4: $\Delta$ - boundaries of measurements; $\boldsymbol{\Delta}$ - the boundaries of measurements following the formation of a crack; $\mathrm{O}-$ the threshold; $\Delta \rightarrow, \Delta \rightarrow-$ the test terminated; - . - remaining deformations on the bending plane

$$
\begin{array}{ll}
1-\bar{\sigma}_{\text {max }}=0,95 \sigma_{y}, & \sigma_{b}= \pm 0,35 \sigma_{y}, \\
1^{\prime}-\bar{\sigma}_{\text {max }}=1,05 \sigma_{y,}, & \sigma_{b}= \pm 0,35 \sigma_{y}, \\
2-\bar{\sigma}_{\text {max }}=1,1 \sigma_{y,}, & \sigma_{b}= \pm 0,45 \sigma_{y}, \\
2^{\prime}-\bar{\sigma}_{\text {max }}=1,2 \sigma_{y}, & \sigma_{b}= \pm 0,55 \sigma_{y}, \\
3^{\prime}-\bar{\sigma}_{\text {max }}=1,2 \sigma_{y,}, & \sigma_{b}= \pm 0,55 \sigma_{y} .
\end{array}
$$

2 paveiksle parodytas jungčiu M52×4 itempties kitimas priklausomai nuo ciklų skaičiaus. Pastebimas iveržimo sumažejimas per pirmuosius $50-100$ ciklu. Vèliau ittemptis smeigèse išlieka tokia pati iki $10^{3}$ ciklu arba iki plyšio atsiradimo. Vystantis plyšiui smeigés itemptis mažeja. Dèl kartotinio perveržimo pasikeičia vienos iš veržlių padètis smeigès atžvilgiu ir kartu plyšys léčiau plinta. Po tam tikro ciklu skaičiaus ittemp- tis vèl mažèja. Viena iš jungčiu išbandyta asimetriniu pulsuojančiu lenkimu iki $10^{3}$ ciklu. Ypatingu skirtumu nuo simetrinio lenkimo nepastebèta ( 2 pav. 3 kreivè).

\section{Plyšio plitimo dèsningumai}

Iveržtoje ir cikliškai lenkiamoje jungtyje plyšio atsiradimo ir plitimo désningumai turi specifiniu požymiŭ, palyginti su cikliškai tempiamomis jungtimis. Suminiai itempimai netolygiai pasiskirsto išilgai vijos. Artejant prie tempiamų sluoksnių vijos apkrova didèja, tolstant mažèja.

Irąžu pasiskirstymo sistemoje smeigè-veržlè tyrimas parodè labiausiai apkrautą vietą, todèl surenkant srieginę jungti viena iš veržliu pastatoma taip, kad smeige gautu toki apkrovima, koks parodytas $3 a$ ir $3 b$ paveiksluose.

Nuo bendros smeigès itempties ir lenkimo poveikio maksimalūs itempimai susidaro tik deformavimo plokštumoje. Nuo to ir priklauso itempimy ir deformaciju būvis bei plyšio susidarymo sąlygos vijos įduboje.

Plyšio atsiradimo ir plitimo analizè parodè, kad plyšys gali bũti vienpusis arba dvipusis. Jeigu plyšys plinta smeigés skerspjūvyje, kaip parodyta 3 a pav., tai jis yra vienpusis arba asimetrinis dvipusis. Jeigu plyšys atsiranda smeigės skerspjūvyje, parodytame 3 b pav., tai jis yra simetrinis dvipusis. Kai plyšys pasiekia kritini dydi $h_{c r}$ arba $h_{c r}=2 h_{c r}^{\prime}$, likusi dalis suyra daugiausia dèl deformacijos energijos, kuri buvo sukaupta ištempiant smeigę. Tuo tarpu ciklinis plyšio plitimas vyksta dèl lenkimo deformacijos.

Itempimu būvio nagrinèjimas ir iražu pasiskirstymo eksperimentiniai tyrimai rodo, kad priklausomai nuo veržlès padèties lenkimo plokštumoje maksimaliu itempimy sriegio iduboje kampas $\alpha$ gali kisti nuo $0^{\circ}$ iki $60^{\circ}$. Plyšio atsiradimo ir plitimo dèsningumai taip pat kinta. Lūžiu analizè parode, kad plyšio atsiradimo iduboje kampas $\alpha$ kinta nuo $0^{\circ}$ iki $45^{\circ}$. Plyšio pradžia nulemia jo tolesni plitimą pagal vieną iš schemu, parodytu 3 paveiksle.

\section{Skaičiavimo analizè}

Srieginiu jungčių stiprumo skaičiavimas pradedamas nuo skaičiavimo pagal leistinus ittempimus, veikiant statinei apkrovai. Skaičiuojant ciklini stiprumą nustatoma faktiška atsarga ir palyginama su reglamentuojamąja arba pageidaujamaja reikšme. Itveržimo proceso metu varžte, be tempimo ịtempimų atsiranda ir 

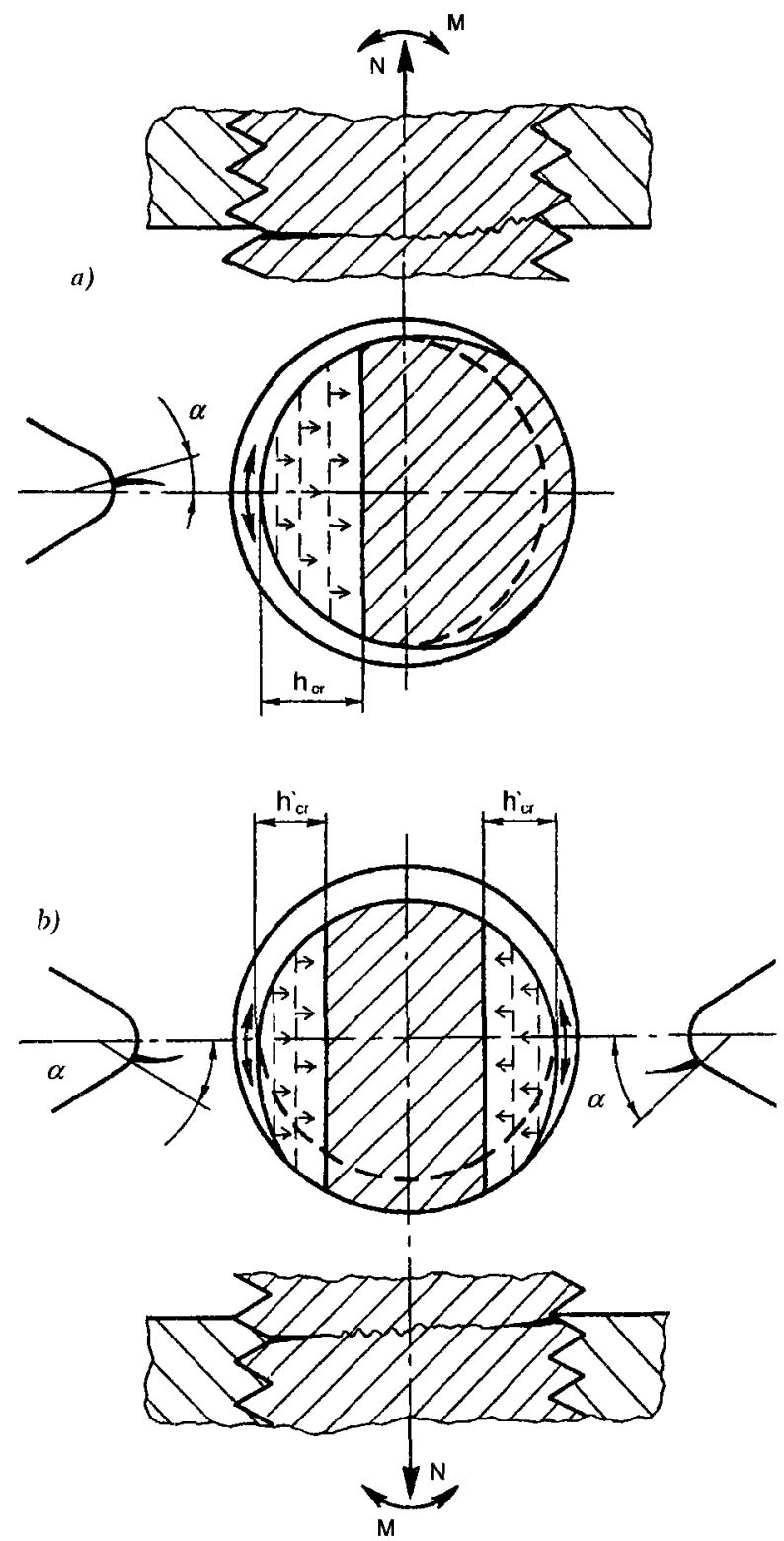

3 pav. Plysio plitimo dèsningumai: $a$ - vienpusis plyšys; $b$ - abipusis plyšys

Fig 3. Regularities of crack propagation: $a$ - one-sided crack; $b$ - two-sided crack

tangentiniai itempimai nuo ịveržimo momento (dèl trinties sriegineje dalyje). Skaičiuojant statini apkrovimą reikia atsižvelgti $\mathfrak{i}$ šiuos tangentinius ịtempimus ir varžto stiprumą tikrinti pagal ekvivalentinius ṫtempimus. Veikiant ciklinei apkrovai, tangentiniai itempimai, atsiradę iveržimo procese, sumažèja arba išnyksta. Jeigu jungties iveržimui taikomas ne veržlès posūkio metodas, o varžto ištempimas, tai tangentiniu itempimų nuo iveržimo nebus.

Itempimai varžtuose ir smeigèse svarbioms jungtims reglamentuojami JAV [11-13] ir Vokietijos normomis. Statinis stiprumas skaiciuojamas pagal minimalias mechanines savybes. Normaliomis eksploatacijos sąlygomis vidutiniai ittempimai skerspjüvyje nuo vidinio spaudimo ir šiluminiu iražų neturi viršyti
2/3 $\sigma_{y}$. Be to, vidutiniai ịtempimai skerspjūvyje kartu su lenkimo ittempimais kraštiniuose sluoksniuose ir tangentiniais itempimais nuo sukimo (jeigu tokie yra) neturi viršyti $\sigma_{y}$. Siekiant užtikrinti normalias eksploatacijos ir bandymo sallygas, reikia apskaiciuoti ciklini stiprumą.

Jungčių skaiciuojamosios nuovargio kreivès (temperatüroms neviršijant $375^{\circ} \mathrm{C}$ ) gaunamos, kai stiprumo atsarga - 2 pagal itempimus arba - 20 pagal ciklų skaičių. Sriegio i̇dubos užapvalinimo spindulys ne mažesnis kaip $0,075 \mathrm{~mm}$, o efektyvusis ittempimu koncentracijos koeficientas - 4. Taip pat reglamentuojamas ir perejimas nuo lygios smeigès dalies i srieginę.

Pagal [14] normas vidutiniai itempimai skerspjūvyje nuo vidinio spaudimo, iveržimo ir siluminiu jègu neturi viršyti $0,65 \sigma_{y}$, o ivertinant ir lenkimą $-0,85 \sigma_{y}$. Itempimai nuo vidinio spaudimo gali būti didesni už analogiškus įtempimus, leidžiamus [11-13] normų. Vidutiniai îtempimai nuo visų apkrovu praktiškai vienodi, o itempimai nuo tempimo ir lenkimo [14] normu griežčiau ribojami negu [11-13] normu.

Nuovargio kreivès pagal [11-13] normas gaunamos, kai deformaciju koncentracijos koeficientas tampriojoje srityje metriniam sriegiui lygus 4 (atsarga $n_{\sigma}=1,5 ; \quad n_{N}=3 ;$ ), o tampriai plastineje srityje gali būti apskaičiuotas pagal Neiberio priklausomybę (atsarga $n_{\sigma}=1,5 ; n_{N}=55$ ) ir siekia 5,5 .

Skaičiuojant pagal nominalius įtempimus nuo vidinio spaudimo nuovargio atsargos koeficientai pagal [14] normas gaunami ne tokie konservatyvūs negu pagal [11-13] normas.

Tačiau tiesioginis nuovargio kreiviu palyginimas, kai ciklu skaičius neviršija $10^{8}$, jskaitant koncentracijos koeficientų padidejima, rodo, kad leistinoji amplitudė ir ciklų skaicius griežčiau reglamentuojami pagal [14] normas, palyginti su [11-13] normomis.

Pagal [14] normas leistinasis cikly skaicius $N_{a d m}$ nustatomas esant tam tikrai jtempiu ciklo amplitudei arba nustatoma leistinoji itempimy amplitudè $\sigma_{a, a d m}$ numacius ciklų skaicių. Tai daroma dviem būdais: pagal normų pateikiamas skaičiuojamąsias nuovargio kreives ir pagal formules, jeigu ciklu skaičius neviršija $10^{6}$. Srieginių jungčiu skaičiavimo metodai tikslinami ir tobulinami eksperimentiniais ir teoriniais tyrimais. Tempiamų ir lenkiamu jungčiu teorinis ir eksperimentinis tyrimas pateiktas [4-8] darbuose. 


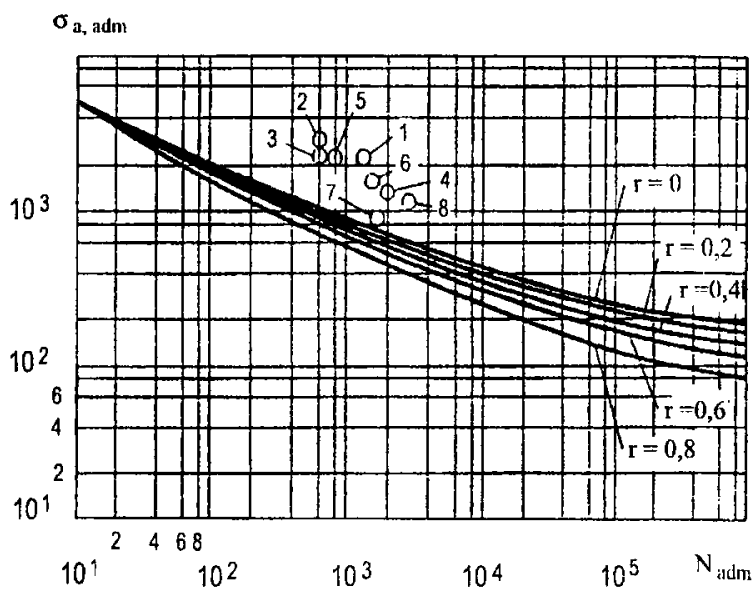

4 pav. Eksperimentiniu rezultatu palyginimas su nuovargio kreivemis pagal [14] normas; $r$ - ciklo asimetrijos koeficientas

Fig 4. Comparison of the experimental data with fatigue curves according norms [14]; $r$ - cycle ratio

5 pav. pateiktas jungčių eksperimentinių rezultatų palyginimas su $[11,12]$ normomis.

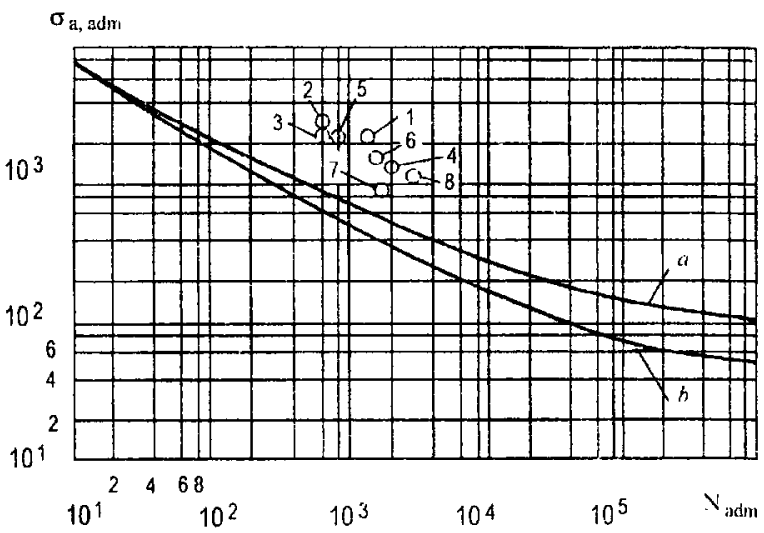

5 pav. Eksperimentiniu rezultaty palyginimas su nuovargio kreivemis pagal [1],12] normas; $a$ - maksimalūs nominaliniai ¡̇tempimai $0,9 \sigma_{y} ; b$ - maksimalüs nominaliniai itempimai $\sigma_{y}$

Fig 5. Comparison of the experimental data with fatigue curves according to norms $[11,12]$ : a - max nominal stress $0,9 \sigma_{y} ; \mathbf{b}-\max$ nominal stress $\sigma_{y}$

4 paveiksle pateiktas srieginiu jungčiu M48 $\times 4$ eksperimentiniu rezultatu pagal plyšio atsiradimą palyginimas su skaičiuojamosiomis nuovargio kreivèmis pagal [14] normas.

Suminiai itempimai nuo tempimo ir lenkimo kraštiniuose varžto sluoksniuose kartais gali viršyti takumo ribą. Atsiradusios netampraus deformavimo salygos per visa ilgi gali pakeisti jungties darbo sąlygas. Netampraus deformavimo procesai sudaro sąlygas suirimui, kuris gali būti lokalizuotas arba bendras. Pirmuoju atveju tai susiję su pažeidimų kaupimųsi, veikiant ciklinei apkrovai, o dèl to atsiranda ir plečiasi plyšys. Antruoju atveju suirimą lemia santykiniu poslinkių kaupimasis. Progresuojantis varžto geometrinis kitimas eksploatuojant nepageidautinas. Tai gali sukelti iveržimo pokyti, irąžu persiskirstymą ir pažeisti jungiamu elementu hermetiškumą.

\section{Išvados}

1. Tyrimai rodo, kad itemptų ir cikliškai lenkiamu srieginiu jungčiu ilgaamžiškumas mažai skiriasi nuo cikliškai tempiamu jungčių ilgaamžiškumo, jeigu lenkimo itempimai neviršija pusès tempimo itempimų.

2. Plyšio plitimo désningumai skiriasi cikliškai lenkiamose ir cikliškai tempiamose srieginèse jungtyse. Esant tam tikrai veržlès ir smeigès padèciai (lenkimo plokštuma sutapatinama su labiausiai apkrauta vieta vijos (duboje) plyšys yra vienpusis. Kitais atvejais, t.y. bet kurioje kitoje veržlès padètyje smeigès atžvilgiu, plyšys yra dvipusis. Vystantis vienpusiam plyšiui ilgaamžiškumas mažèja, t. y. toks plyšio plitimas yra pavojingesnis.

3. Eksperimentinių rezultatų (makroplyšio atsiradimas) palyginimas su skaičiavimo normomis (nuovargio kreivès) rodo, kad atsarga pagal itempimus ir pagal ciklu skaičiu yra pakankama.

\section{Literatūra}

1. M. Leonavičius, S. Stupak. ไ̨tempimų būvio įtaka plyšio susidarymui sriegio iduboje // Mechanika, Nr. 2. Kaunas: Technologija, 1998, p. 5-9.

2. A. Krenevičius, M. Leonavičius. Srieginiu jungčiu M16 iveržimas ir atsparumas mažacikliam lenkimui // Statyba, IV tomas, Nr. 2. Vilnius: Technika, 1998, p. 117-123.

3. M. Leonavičius, A. Krenevičius, $M$. Šukšta. Progresuojantis deformacijų kaupimasis mažaciklio lenkimo veikiamose srieginese jungtyse M16 // Statyba, IV tomas, Nr. 2. Vilnius: Technika, 1998, p. 124-128.

4. M. Leonavičius, A. Krenevičius. Prisitaikomumo ir atsparumo mažacikliam irimui varžtinèse jungtyse skaiciavimas // Mechanika, Nr. 1. Kaunas: Technologija, 1995, p. 30-32.

5. M. Leonavičius, M. Šukšta. Mažaciklio irimo plysio vystymasis ir prisitaikomumas varžtinèse jungtyse // Mechanika, Nr. 3. Kaunas: Technologija, 1998, p. 16-18.

6. М. Ляонавичюс. Сопротивление деформированию резьбовых соединений при жестком изгибном нагружении // Методы решения задач строительной механики. Вильнюс, 1987, с. 118-124 (Lietuvos aukštujy mokykly mokslo darbai. Lietuvos mechanikos rinkinys, Nr. 29).

7. M. Leonavičius, M. Šukšta. The bolt-with-a crack shakedown estimation by the method of additional load // Statyba, Nr. 1(9). Vilnius: Technika, 1997, p. 74-77.

8. M. Leonavičius and A. Krenevičius. Shakedown and Failure of the Threaded Joints under Low Cyclic Loading // Journal of Constructional Steel Research, 
Vol. 46, 1998. The Steel Construction Institute. Elsevier, p. 452-453. Special issue on CDROM.

9. International standard. Threaded faster. Axial load fatigue testing. Test methods and evaluation of results. ISO 3800: 1993(E). Printed in Switzerland. $17 \mathrm{p}$.

10. И. А. Биргер, Г. Б. Иосилевич. Резьбовые соединения. Москва: Машиностроение, 1978. $256 \mathrm{c}$.

11. ASME Boiler and Pressure Vessel Code, Sec. III // Rules for Construction of Nuclear Power Plant Components, Div. I., Subset. NB, 1995, p. 87-92.

12. ASME Boiler and Pressure Vessel Code, Sec. III // Rules for Construction of Nuclear Power Plant Components, Div. I., Subset. NB, 1995, p. 6-12.

13. Komponenten des Primakreises von Leichtwassereactoren. Teil: Auslegung. Konstruktion und Berechnung, KTA 3201. 2, nov. 1982.

14. Нормы расчета на прочность оборудования и трубопроводов атомных энергетических установок. Москва: Энергоатомиздат, $1989.525 \mathrm{c.}$

15. М.-К. В. Ляонавичюс, Б.-С. И. Мажуолис, А. А. Спейчис, В. А. Каган. Влияние изгиба на сопротивление малоцикловой усталости резьбовых соединений больших диаметров // Mechanine technologija, IX t. Vilnius, 1979, p. 142-144.

Iteikta 19990628

\section{ANALYSIS OF EXPERIMENT AND CALCULATION OF THE THREADED JOINTS UNDER TENSION AND CYCLIC BENDING}

\author{
A. Krenevičius, S. Stupak, M. Šukšta, M. Leona- \\ vičius
}

\section{$\mathrm{S} \mathrm{u} \mathrm{m} \mathrm{m} \mathrm{a} \mathrm{r} y$}

The effect of individual elements of the system "bolt-nut" under tension and bending on the cyclic strength is a complicated and insufficiently clear subject. The data presented in the works of the laboratories of strength mechanics and those of the present authors have been obtained when the ratio of bending and tension stress caused by eccentrically applied tension force was from 0 to 1.5 . If stresses caused by bending account for $0.25 \sigma_{y}$ of tension stresses, the strength to low-cycle fatigue somewhat increases. When $\sigma_{m}=1.5 \sigma_{n}$, the decrease in longevity is observed. The results obtained, however, differ insignificantly from the longevity of threaded joints under cyclic tension as long as bending stresses do not exceed $0.5 \sigma_{y}$. A comprehensive experimental study of these problems and the analysis are presented in the works of the present authors.

One of the main factors determining the cyclic strength of the system "bolt-nut" is the distribution of internal resultants.

The distribution of internal resultants after the threaded joint has been tightened up to $\sigma_{t}=0.6 \sigma_{y}$ corresponds to the general rule which is characteristic of joints under tension. During the first stress cycle due to ben- ding deformations in the cavity of turns of the threads also correspond to the general rule of internal resultant distribution of joints under tension in the layers under tension. In layers under compression, the general effect of tightening and the nut distort the generally accepted laws.

The analysis of the formation of the crack and its propagation showed there can be either a single or double crack. When the crack reaches the critical size, the remaining part fractures mostly on account of the deformation energy which was accumulated when stretching the stud, whereas the cyclic propagation of the crack takes place due to bending deformations.

Under fluctuating loads threaded joints loosen. Therefore tightness of a vessel subject to high pressure may be lost or the maintenance regime of some device may be disturbed. Due to crushing of contacting surfaces of transmission parts and the thread, spontaneous turn of the nut, plastic deformations in the thread and transmission parts, tightening of the bolt and tightness of transmissions parts may decrease. Studs of demountable joints of energy devices are calculated in accordance with the norms of the Russian Federation and the ASME code. The calculation methods coincide in essence, they are based on similar marginal states. Nevertheless, there exist some differences. The article gives a comparison of some calculating rules for low cycle fracture resistance of the threaded joints.

Algimantas KRENEVIČIUS. Doctor, Associate Professor. Dept of Strength of Materials. Vilnius Gediminas Technical University, Saulètekio al. 11, 2040 Vilnius, Lithuania.

Doctor (structural mechanics, 1983). Research interests: fracture mechanics and creep.

Marijonas ŠUKŠTA. Doctor, Associate Professor. Dept of Strength of Materials. Vilnius Gediminas Technical University, Sauletekio al. 11, 2040 Vilnius, Lithuania.

Doctor (structural mechanics, 1984). Research interests: analysis of elastic-plastic strain hardening structures and shake-down.

Stanislav STUPAK. Doctor, Associate Professor. Dept of Strength of Materials. Vilnius Gediminas Technical University, Sauletekio al. 11, 2040 Vilnius, Lithuania.

Doctor (structural mechanics, 1978). Research interest: analysis of elastic-plastic strain hardening structures and shake-down; fracture mechanics.

Mindaugas LEONAVIČIUS. Doctor, Associate Professor. Dept of Strength of Materials. Vilnius Gediminas Technical University, Sauletekio al. 11, 2040 Vilnius, Lithuania.

Doctor (structural mechanics, 1977). Research interests: fracture mechanics and shakedown. 